\title{
PHARMACY
}

\section{SPECIFIC FEATURES ANALYSIS OF INHALATION MEDICATION USE TO TREAT BRONCHIAL ASTHMA IN CHILDREN}

\author{
I. A. Kostiuk, K. L. Kosyachenko \\ National Medical University named after O.O. Bogomolets, Kyiv, Ukraine \\ Department of Organization and Economy of Pharmacy
}

DOI: https://doi.org/10.31435/rsglobal_ws/31102019/6721

\section{ARTICLE INFO}

Received: 10 August 2019

Accepted: 08 October 2019

Published: 31 October 2019

\section{KEYWORDS}

bronchial asthma,

children,

inhalation therapy,

inhaler,

pharmacists.

\begin{abstract}
The article focuses on analysis of the main system types to deliver aerosol medication. They have their advantages and disadvantages and used in different age range patient. The main specific features of using different inhalers and medications have been determined. The algorithm to choose an inhaler type for children with bronchial asthma has been suggested which can be which can be insured by pharmacists to provide pharmaceutical care. The content analysis of the Instructions to use inhalation medications has been done. The need to enlarge the given information and to provide schematic addition of the inhalation procedure to the instruction has been defined.
\end{abstract}

Citation: I. A. Kostiuk, K. L. Kosyachenko. (2019) Specific Features Analysis of Inhalation Medication Use to Treat Bronchial Asthma in Children. World Science. 10(50), Vol.1. doi: 10.31435/rsglobal_ws/31102019/6721

Copyright: (C) 2019 I. A. Kostiuk, K. L. Kosyachenko. This is an open-access article distributed under the terms of the Creative Commons Attribution License (CC BY). The use, distribution or reproduction in other forums is permitted, provided the original author(s) or licensor are credited and that the original publication in this journal is cited, in accordance with accepted academic practice. No use, distribution or reproduction is permitted which does not comply with these terms.

Introduction. New systems to deliver medications while treating bronchopulmonary diseases have become very popular today. Global Initiative for Asthma recognizes inhalation therapy as that which has the leading role to treat bronchial asthma (BA). Due to this system of delivering, medication gets to the target organ and causes no side reactions in other body systems. Practicing inhalation therapy in-patients and out-patients leads to decrease of bronchial asthma recurrence rate, hospitalization, and also improve patent's and their families' quality of life [1].

Although the national and international standards and protocols of BA treatment unify the approach of assessing and treating patients, but it is not always possible to control the clinical disease manifestations in practice. Patients' mistakes while using an inhaler are one of the reasons of uncontrolled BA frequency because wrong technique cannot provide a delivery of the necessary medication dose to the lungs [1,2].

At present it is essential for medical officers and pharmacists to teach patients the inhalation technique. The foreign professional literature states that $88 \%$ patients with BA make at least one mistake while using an inhaler. According to the research taken in Ukraine $92 \%$ of children break do not follow the instructions of inhalation technique or even do it wrong $[3,4]$.

Nowadays the pharmaceutical market of Ukraine offers a wide range of medications and medical products for inhalation therapy. The choice of the inhaler for children should depend on patients' cognitive abilities. So, children under 3, as a rule, cannot perform specific breathing maneuvers, therefore they are recommended to use a facial mask for inhalation. The best way is to teach children how to use a mouthpiece because breathing through this device increase the level of medications depositing in lungs [5].

Inhalation therapy for children with BA has been researched by many scientists. The authors have studied efficiency of delivering inhalation medications particularly to children with BA with the 
help of different inhalers. However, there is no research done on the instruction content of medical use of inhalation medications for children with BA.

The purpose of the research. To study different types of devices and the principles of their work for inhalation therapy and to analyze the instructions content of medication use in inhalation for children with BA are our purpose of the research.

The materials and methodology of the research. The national and foreign professional literature has been studied; the content of the instructions how to use medications in medical practice to treat children with BA has been analized. The method of systematic structural analysis has been applied.

The research results. Now the pharmaceutical market of Ukraine can offer many different inhalation devices. Unfortunately, pharmacists are said to have poor knowledge of product range, their use and care. They also note that there is lack of reliable professional source of information which can help them to learn the main characteristics of inhalation devices.

Currently there are several system types to deliver aerosol medication:

1. Metered-dose Aerosol Inhaler (MAI). It was introduced into practice in 1950s as the first portable multi-dose inhaler. Medications inhaled with the help of MAI include chlorofluorohydrocarbon propellant (CFH) and hydrofluoric alkane (HFA). One of the specific features to consider is that at the first use and after a long break before using the inhaler one should «refresh» it (spray 2-4 doses in the air).

To avoid the problems of synchronization while using MAI, it is recommended to use an intermediate reservoir which connects the inhaler and the patient's respiratory tracts - a spacer. Spacers are divided into 2 types: small $(130-300 \mathrm{ml})$ and big $(600-800 \mathrm{ml})$ volume. Some of them are supplied with a whistle which signals at a rather speedy inhale. It is very convenient because the patient can practice inhaling technique and take the inhale which will not produce a sound signal. Spacers are used for several months, hence they need hygienic processing. Spacers are washed in mild solution of dishwashing liquid and dried naturally. Manufactures recommend disinfecting spacers 1 time per week or 1 time per month $[6,8]$.

2. Breath-activated Inhaler (BAI) is an inhalation device which can help to avoid the problem of insufficient coordination of inhale to the inhaler activation while using standard MAI.

3. Powder Inhaler (PI). It is a breath-activated inhaler type that has a small size. Patients should be taught to exhale to the level of functional lungs residual volume before starting inhalation. It is forbidden to exhale into the inhaler as one can blow out the prepared dose of medication from the inhaler. The most frequent mistake while using such type of inhalers is when patients do not take a deep exhale before inhalation [6-8].

4. Nebulizer is a device to generate aerosol which contains dispersed particles. Its advantage is that it can disperse high doses of medication which MAI and PI cannot produce. Many nebulizers are supplied with facial masks and can be used for children under 2. In case the patient cannot tolerate the mask, it is recommended to use a mouthpiece for inhalation [9].

Table 1. Advantages and disadvantages of different inhaler devices

\begin{tabular}{|c|c|c|}
\hline Inhaler type & Advantages & Disadvantages \\
\hline 1 & 2 & 3 \\
\hline MAI & $\begin{array}{l}\text { - portability; } \\
\text { - convenience; } \\
\text { - high speed of inhalation procedure; } \\
\text { - no risk of contamination; } \\
\text { - low price }\end{array}$ & $\begin{array}{l}-\quad \text { synchronizing the patient's inhale and } \\
\text { the inhaler's activation; } \\
-\quad \text { high speed of aerosol spraying (over } \\
30 \mathrm{~m} / \mathrm{s}) \text {; } \\
-\quad \text { low depositing in lungs and high - in } \\
\text { oropharynx; } \\
-\quad \text { irritant effect of the propellant to } \\
\text { mucosa of respiratory tracts (RT); } \\
-\quad \text { freon can cause cough at a «cold } \\
\text { effect»; } \\
-\quad \text { difficulty to determine the medication } \\
\text { dose leftover }\end{array}$ \\
\hline $\begin{array}{l}\text { Breath- } \\
\text { activated } \\
\text { Inhaler }\end{array}$ & $\begin{array}{l}\text { - } \text { simple inhalation technique; } \\
\text { - } \text { high lungs deposition }\end{array}$ & $\begin{array}{l}\text { - if breath-activated, the speed of } \\
\text { inhalation flow is not controlled }\end{array}$ \\
\hline
\end{tabular}


Continuation of table 1.

\begin{tabular}{|c|c|c|}
\hline 1 & 2 & 3 \\
\hline PI & $\begin{array}{l}\text { - compact; } \\
\text { - medication particles are constantly } \\
\text { inhaled due to the patient's inhaling; } \\
\text { - high speed of inhalation procedure; } \\
\text { - some PI are supplied with a dose } \\
\text { meter }\end{array}$ & $\begin{array}{l}\text { - loss of some medication in the inhaler; } \\
\text { - high depositing in oropharynx; } \\
\text { - efficiency decrease of some powders } \\
\text { at storage; } \\
\text { - irritant effect of powder to mucosa of } \\
\text { RT which causes cough and } \\
\text { bronchospasm }\end{array}$ \\
\hline Nebulizer & $\begin{array}{l}-\quad \text { simple technique; } \\
\text { - economy of medication use; } \\
\text { - no necessity to synchronize the } \\
\text { patient's inhale and inhalation; } \\
\text { - aerosol cloud has no propellants } \\
\text { which cause RT; } \\
\text { - creating higher concentration of } \\
\text { medications in RT }\end{array}$ & $\begin{array}{l}\text { - } \text { need of energy source; } \\
- \text { inhalation time can increase; } \\
\text { - a risk of bacterial contamination in } \\
\text { case of poor hygiene; } \\
\text { - high price }\end{array}$ \\
\hline
\end{tabular}

We have analyzed the principles of using different types of inhaler devices and have identifies a several specific features. They relate to the start of inhaler work, care rules, and also patient's activities after finishing inhalation (table 2).

Table 2. Specific features of different inhaler types for the pharmacist to consider while selling medications

\begin{tabular}{|l|l|}
\hline \multicolumn{1}{|c|}{$\begin{array}{c}\text { Inhaler } \\
\text { type }\end{array}$} & \multicolumn{1}{c|}{ Specific features } \\
\hline MAI & $\begin{array}{l}- \text { M which is delivered by the inhaler to the mouth can be tasteless or even felt in the } \\
\text { mouth } \\
-\quad \text { it is necessary to keep, disinfect and «refresh» the inhaler according to the } \\
\text { manufacture's instruction } \\
-\quad \text { if inhalation glucocorticosteroids (IGCS) prescribed, it is necessary to use a spacer } \\
\text { or a valve spacer } \\
-\quad \text { it is necessary to rinse the mouth after IGCS inhalation even while using a spacer } \\
-\quad \text { spacer should be disinfected according to the instruction }\end{array}$ \\
\hline BAI & $\begin{array}{l}- \text { the patient can define if the medications dose is received by the taste or sound which } \\
\text { confirms medication release }\end{array}$ \\
\hline PI & $\begin{array}{l}- \text { before inhaling medications with the help of PI it is necessary to exhale without the } \\
\text { inhaler } \\
\text { first, it is necessary to take a strong inhale rather than gradually increase inhale } \\
\text { speed }\end{array}$ \\
\hline Nebulizer & $\begin{array}{l}\text { - if it is impossible to inhale through the mouthpiece, one should use a facial mask } \\
- \text { it is necessary to rinse Nebulizer after every use } \\
- \text { a patient should be informed that term of nebulizer change is determined in the } \\
\text { instruction }\end{array}$ \\
\hline
\end{tabular}

Having systemized the obtained results we have developed an algorithm of choosing an inhaler type for the children with BA (Figure 1). One can see that this algorithm supposes the choice of the inhaler according to the age and cognitive characteristics of the child.

Patients have a right to be well informed of medication use by the doctor or pharmacists, or any other information source including medication instruction (further Instruction). The instruction should contain the simplified data which can be understood by the patient themselves or with the doctor's or pharmacist's help to get all necessary information. We have analyzed the content of medication instructions which are used for inhalation therapy of children with BA $[10,11]$. The sample includes 25 medications, the most of which are represented by the following medications, such as powder (36\%) and aerosol (32\%) (Figure 2). 


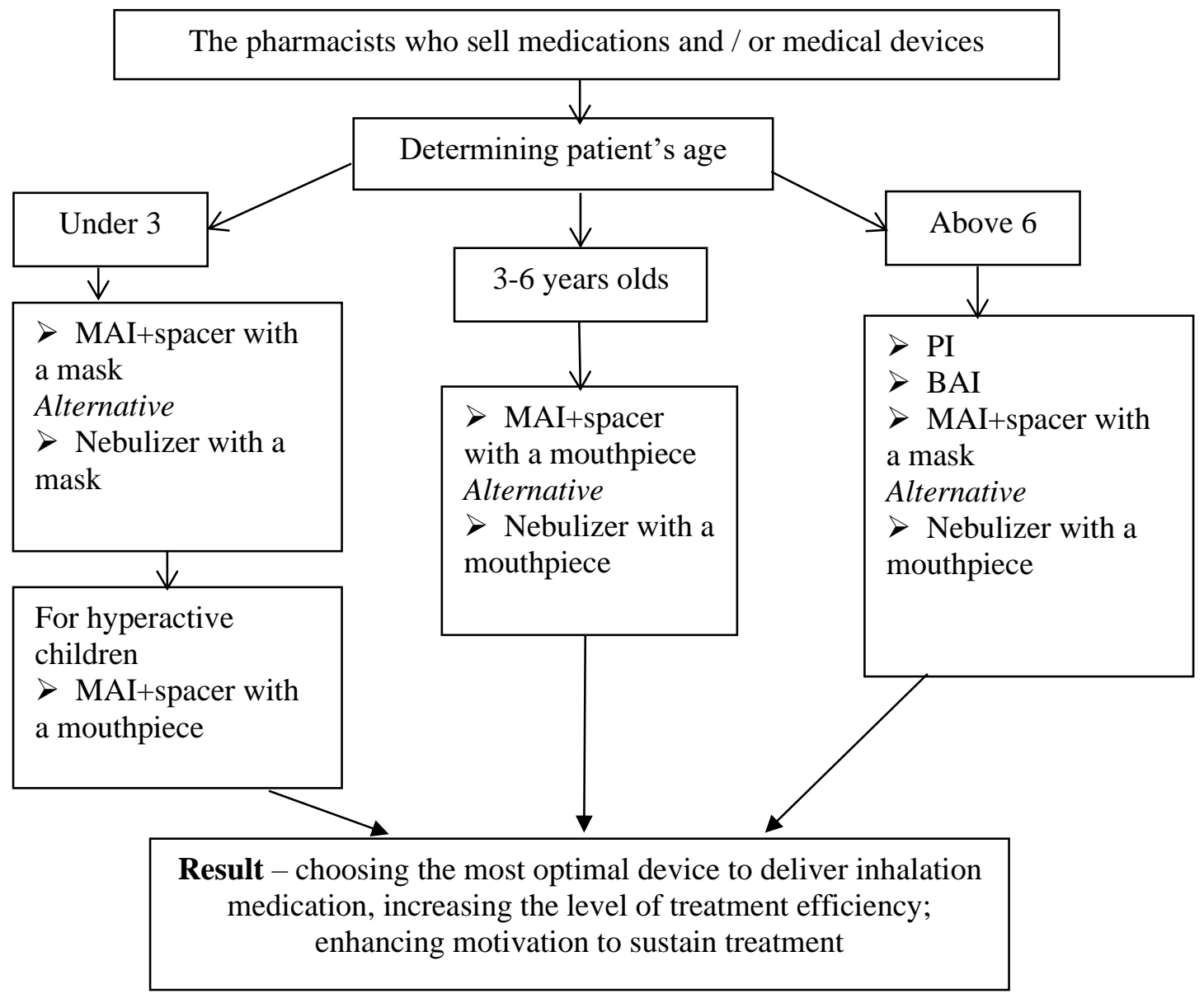

Fig. 1. Algorithm to choose the inhaler type for children with BA

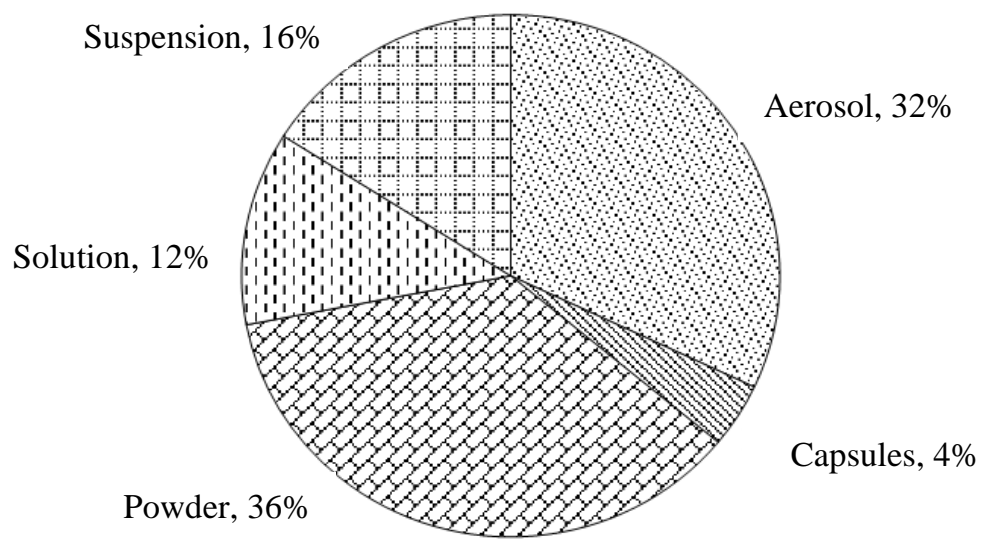

Fig. 2. Distribution of medication forms used in inhalation therapy of children with BA

In general, the Instruction section «Directions for use and dose» of the medication group under analysis has the following structure:

1. Dose

2. Inhaler testing

3. Inhaler use

4. Cleaning

5. Notes (recommendations).

However, the Instruction of medication for inhalation therapy to use in Nebulizer includes information about the solvent and extra components of the inhaler (Table 3 ). 
Table 3. The structure characteristic of medication instructions used in inhalation therapy of children with BA

\begin{tabular}{|c|c|c|}
\hline $\begin{array}{l}\text { Instruction } \\
\text { subsection }\end{array}$ & Description & Medications which include \\
\hline Inhaler testing & $\begin{array}{l}\text { Peculiarities of the first } \\
\text { inhalation start and every next } \\
\text { use }\end{array}$ & $\begin{array}{l}\text { Airtek, Budesonide-inteli, Ventolin Evohaler, } \\
\text { Pulmicort turbuhaler, Salbutamol, Seretide } \\
\text { Diskus, Seretide Evohaler, Symbicort } \\
\text { turbuhaler, Flixotide Evohaler, Formoterol } \\
\text { easyhaler, Fortex }\end{array}$ \\
\hline Inhaler use & $\begin{array}{l}\text { Stage-by-stage process of } \\
\text { inhalation with set timing }\end{array}$ & $\begin{array}{l}\text { Airtek, Ventolin Evohaler, Zafiron, Pulmicort } \\
\text { turbuhaler, Salbutamol, Seretide Diskus, } \\
\text { Seretide Evohaler, Symbicort turbuhaler, } \\
\text { Flixotide Evohaler, Flutixon, Formoterol } \\
\text { easyhaler, Fortex }\end{array}$ \\
\hline Cleaning & $\begin{array}{l}\text { Description of process and } \\
\text { cleaning, and also its } \\
\text { frequency }\end{array}$ & $\begin{array}{l}\text { Airtek, Budesonide-inteli, Ventolin Evohaler, } \\
\text { Zafiron, Pulmicort turbuhaler, Salbutamol, } \\
\text { Seretide Diskus, Seretide Evohaler, Symbicort } \\
\text { turbuhaler, Flixotide Evohaler, Flutixon, } \\
\text { Formoterol easyhaler, Fortex }\end{array}$ \\
\hline \multirow[t]{4}{*}{$\begin{array}{l}\text { Notes } \\
\text { (recommendations) }\end{array}$} & $\begin{array}{l}\text { Rinse your mouth or throat } \\
\text { after inhalation }\end{array}$ & $\begin{array}{l}\text { Airtek, Budesonide-inteli, Pulmicort } \\
\text { turbuhaler, Flixotide Evohaler }\end{array}$ \\
\hline & Use a spacer & $\begin{array}{l}\text { Ventolin Evohaler, Salbutamol, Flixotide } \\
\text { Evohaler }\end{array}$ \\
\hline & $\begin{array}{l}\text { Test the first several } \\
\text { inhalations in front of the } \\
\text { mirror to control the technique }\end{array}$ & Airtek, Ventolin Evohaler \\
\hline & $\begin{array}{l}\text { Tasteless or medication taste } \\
\text { in the mouth }\end{array}$ & Pulmicort turbuhaler \\
\hline \multicolumn{3}{|c|}{ For nebulizer therapy } \\
\hline \multirow[t]{3}{*}{ Solvent } & $\begin{array}{l}\text { Saline }(0,9 \%) \text { and its } \\
\text { necessary volume }\end{array}$ & Berodual, Pulmicort \\
\hline & Solutions for inhalation & Pulmicort \\
\hline & Undiluted solution & Ventolin nebules, Nebutamol \\
\hline Nebulizer use & $\begin{array}{l}\text { Stage-by-stage process of } \\
\text { inhalation }\end{array}$ & $\begin{array}{l}\text { Ventolin nebules, Nebufluzon, Flixotide } \\
\text { nebules }\end{array}$ \\
\hline \multirow[t]{2}{*}{ Cleaning } & Rinse & Nebutamol, Pulmicort \\
\hline & No information & $\begin{array}{l}\text { Berodual, Ventolin nebules, Nebufluzon, } \\
\text { Flixotide nebules }\end{array}$ \\
\hline \multirow[t]{2}{*}{$\begin{array}{l}\text { Notes } \\
\text { (recommendations) }\end{array}$} & Use a mouthpiece or a mask & $\begin{array}{l}\text { Berodual, Ventolin nebules, Nebutamol, } \\
\text { Nebufluzon, Pulmicort, Flixotide nebules }\end{array}$ \\
\hline & $\begin{array}{l}\text { Use face lotion or rinse it } \\
\text { thoroughly }\end{array}$ & Nebufluzon, Pulmicort, Flixotide nebules \\
\hline
\end{tabular}

Having analyzed the content of Instructions, we can state that the information as to using inhalation medication is given fully in every instruction. 8 medications (32\%) have the subpart «Inhaler Use» supplied with a scheme of inhalation stages. Providing the patient the information in an easy way is convenient and necessary for the pharmacists to raise sanitary awareness. Much information given in the instruction, a number of problems as to use the researched medications, for children in particular still remain. Thus, only16\% of Instructions have the subpart «For Children» which focuses that small children need help and it may be necessary for adults to assist children while using an inhaler or learn the technique of inhalation together. The rules of holding the inhaler are described for older children, e.g. the instructions to use Ventolin Evohaler, Salbutamol, and Seretide Evohaler. Although all 25 researched medications are used in pediatric practice.

Medications for Nebulazer inhalation have no schematic instruction, and the algorithm of providing the information as to medication use is rather short. 


\section{Conclusions.}

1. The main system types of delivering aerosol medication have been analyzed. They have their advantages and disadvantages and used for different age range patients.

2. The main specific features of using different inhalation medications and medical products have been established. The pharmacist should draw patient's attention to these features if the device is for children with BA.

3. The algorithm of choosing the inhaler for children with BA has been suggested which can be insured by pharmacists to provide pharmaceutical care.

4. We have analyzed the content of Instructions and we can state that the information as to using inhalation medication in the subpart «How to use and doses» is given in a different way and needs additions for some medications. Thus, only $32 \%$ of Instructions is supplied with a scheme to follow the inhalation procedure stages and only $16 \%$ of Instructions have the subpart «For Children» which emphasizes necessity for adults to assist children to learn the technique of inhalation by the children.

\section{REFERENCES}

1. Global Initiative for Asthma. Global Strategy for Asthma Management and Prevention (2019 Update):201. Available from: www.ginasthma.org

2. Inhalation therapy in the next decade: Determinants of adherence to treatment in asthma and COPD / [C. Donner, S. Amaducci, E. Bacci та ін.]. // Monaldi Archives for Chest Disease. - 2018. - P. 14-36.

3. Nedelska S.M. Efektivnist riznykh zasobiv dostavky inhaliatsiinykh preparative u ditei iz bronkhialnoiu astmoiu / S.M. Nedelska, O.D. Kuznetsova, N.M. Taran, A. Aleschenko // Zdorovie rebenka. Tom 12, №1, 2017. S. 13-17.

4. Rechkina O.O. Pomylki vykorystannia dozovanykh aerozolnykh inhaliatoriv pry bronkhialnii astmi u ditei / O.O. Rechkina, A.S. Doroshenkova // Astma ta alergiia. №4. 2014. S.28-32.

5. Okhotnikova O.M. Osnovy inhaliatsiinoi terapii. Prystroi, scho dostavliaiut likarski zasoby v dykhalni shliakhy / O.M. Okhotnikova // Klinichna imunologiia. Alergoliia. Infektologiia. № 2(99) 2017.S. 18-31

6. Mishandling of pMDI and DPI inhalers in asthma and COPD - Repetitive and non-repetitive errors / [K. Luczak-Wozniak, M. Dabrowska, I. Domagala et al.]. // Pulmonary Pharmacology \& Therapeutics. - 2018. - №51. - P. 65-72.

7. The Inhalation Characteristics of Patients When They Use Different Dry Powder Inhalers / [W. Azouz, P. Chetcuti, H. Hosker et al.]. // Journal of Aerosol Medicine and Pulmonary Drug Delivery. - 2015. - №28. - P. 35-42.

8. Sukhan V.S. Zastosuvannia inhaliatsiinoi terapii u khvorykh na bronkhialnu astmu (ohlid literatury) / V.S. Sukhan // Ukraina. Zdorov'ia natsii. 2015. №3 (35). S. 136-140.

9. Sukhan V.S. Nebulaizerna terapiia yak metod inhaliatsiinoi aerozolterapii u likuvanni khvorykh na bronkhialnu astmu / V.S. Sukhan // Naukovyi visnyk Uzhgorodskoho universitetu, seriia «Medytsyna». 2015. №1 (51). S. 279-283.

10. Nakaz MOZ Ukrainy vid 08.10.2013 № 868 «Pro zatverdzhennia ta vprovadzhennia medykotekhnologichnykh dokumentiv zi standartyzatsii medychnoi dopomohy pry bronkhialnii astmi» URL: https://zakon.rada.gov.ua/rada/show/v0868282-13.

11. Normativno-dyrektyvni dokumenty MOZ Ukrainy: web-site. URL: http://mozdocs.kiev.ua/. 